\title{
PENGARUH KOMPETENSI, INDEPENDENSI, PROFESIONALISME DAN KEPATUHAN PADA \\ KODE ETIK AUDITOR INVESTIGATIF TERHADAP EFEKTIVITAS PELAKSANAAN \\ PROSEDUR AUDIT DALAM PEMBUKTIAN FRAUD (KECURANGAN)
}

(Studi Kasus pada Perwakilan Badan Pengawasan Keuangan dan Pembangunan

Provinsi Jawa Tengah)

Achmad Zulfikar Fauzi1'), Halim Dedy Perdana'1), Sulardi1)

1)Fakultas Ekonomi dan Bisnis Universitas Sebelas Maret

\begin{abstract}
Abstrak
Penelitian ini bertujuan untuk mengetahui pengaruh kompetensi, independensi, profesionalisme dan kepatuhan pada kode etik auditor investigatif terhadap efektifitas pelaksanaan prosedur audit dalam pembuktian fraud (kecurangan). Semua variabel diukur menggunakan daftar pertanyaan/kuisioner yang dibagikan ke sampel. Populasi dalam penelitian ini adalah seluruh auditor pada Perwakilan BPKP Provinsi Jawa Tengah. Penelitian ini menggunakan tekhnik random sampling. Peneliti menyebarkan 50 kuisioner kepada auditor Perwakilan BPKP Provinsi Jateng, sedangkan jumlah kuisioner yang memenuhi kriteria sebanyak 42 eksemplar. Pengujian hipotesis penelitian ini menggunakan analisis regresi berganda. Hasil uji dari regresi berganda menunjukkan bahwa kompetensi, independensi, profesionalisme dan kepatuhan pada kode etik auditor investigatif berpengaruh positif terhadap efektifitas pelaksanaan prosedur audit dalam pembuktian fraud. Kepatuhan pada kode etik memiliki tingkat signigikansi yang paling tinggi dibandingkan tiga variabel lainya.

Kata Kunci: Kompetensi, Independensi, Profesionalisme, Kepatuhan pada Kode Etik, Auditor Investigatif, Efektifitas Pelaksaanaan Prosedur Audit, Pembuktian Fraud.
\end{abstract}

\section{PENDAHULUAN}

Salah satu tujuan Negara Kesatuan Republik Indonesia sesuai yang tercantum dalam pembukaan UUD tahun 1945 adalah memajukan kesejahteraan umum. Kesejahteraan rakyat dicapai melalui pembangunan nasional dan pelaksanaan anggaran pendapatan dan belanja negara/daerah yang transparan, akuntabel dan bebas korupsi. Sesuai dengan Djelantik (2008) yang menyebutkan bahwa kemajuan bangsa yang ditunjukan dengan meningkatnya kesejahteraan masyarakat tidak akan tercapai jika praktek-praktek korupsi masih tetap berlangsung. Berdasarkan gambaran dari Association of Certified Fraud Examiners (ACFE) menyatakan bahwa korupsi adalah salah satu cabang dari fraud. Dengan kata lain, pembangunan nasional dan pelaksanaan anggaran pendapatan dan belanja negara/daerah harus terbebas dari "fraud". 
Audit untuk membuktikan ada atau tidaknya suatu fraud disebut Audit Investigatif. Dalam pelaksanaanya seorang auditor investigatif harus melaksanakan prosedur audit yang efektiv sehingga dapat mengumpulkan bukti-bukti yang relevan, kompeten dan cukup sebagai pembuatan simpulan audit yang memuat informasi mengenai apa, dimana, siapa, kenapa, kapan dan bagaimana proses penyimpangan terjadi. Jika prosedur audit tidak dilaksanakan secara efektiv, dikhawatirkan hasil audit investigatif tidak dapat digunakan sebagai dasar penentuan ada atau tidaknya fraud pada saat persidangan.

Lubis (2009) menyebutkan bahwa kompetensi teknis yang harus dimiliki oleh auditor adalah auditing, akuntansi, administrasi pemerintahan dan komunikasi. Hasil suatu audit tidak akan berkualitas jika pada saat pelaksanaan prosedur audit dilakukan oleh auditor yang terganggu keindependensiannya. Sesuai dengan PER/05/M.PAN/03/2008 yang menyebutkan "dalam semua hal yang berkaitan dengan audit, APIP harus independen dan para auditornya harus obyektif dalam pelaksanaan tugasnya". Mulyadi dalam (2011) menyebutkan bahwa Independensi adalah keadaan bebas dari pengaruh, tidak dikendalikan oleh pihak lain, tidak tergantung pada orang lain.

Jeffrey dan Weatherholt dalam Malikha (2010) menguji hubungan antara komitmen professional, pemahaman etika dan sikap ketaatan terhadap aturan. Hasilnya menunjukkan bahwa akuntan dengan komitmen professional yang kuat maka perilakunya lebih mengarah kepada ketaatan terhadap aturan dibandingkan dengan akuntan dengan komitmen professional yang rendah. Agar prosedur audit dapat dilaksanakan dengan efektiv, maka auditor harus memenuhi kode etik. Kode etik bagi APIP diatur dalam Peraturan Menteri Negara Pemberdayaan Aparatur Negara Nomor Per/05/M.Pan/03/2008 tentang Standar Audit Aparat Pengawasan Internal Pemerintah (APIP). Kode etik profesi merupakan norma yang ditetapkan dan diterima oleh sekelompok profesi, yang mengarahkan atau memberi petunjuk kepada anggotanya bagaimana seharusnya berbuat dan sekaligus menjamin mutu profesi itu dimata masyarakat. Apabila anggota kelompok profesi itu menyimpang dari kode etiknya, maka kelompok profesi itu akan tercemar di mata masyarakat.

Berdasarkan latar belakang diatas, peneliti melakukan penelitian dengan judul “Pengaruh Kompetensi, Independensi, Profesionalisme dan Kepatuhan pada Kode Etik Auditor Investigatif terhadap Efektivitas Pelaksanaan Prosedur Audit dalam Pembuktian Fraud (Kecurangan)".

\section{Tinjauan Literatur dan Perumusan Hipotesis}


Pengaruh Kompetensi, Independensi, Profesionalisme Dan Kepatuhan...

\section{Teori Segitiga Fraud}

Cressey (1953) menyatakan terdapat tiga kondisi yang selalu hadir saat terjadi kecurangan dalam laporan keuangan. Ketiga kondisi tersebut adalah tekanan (pressure), kesempatan (opportunity), dan rasionalisasi (rationalization). Teori yang dikemukakan oleh Cressey tersebut dikenal dengan istilah fraud triangle. Tekanan adalah dorongan yang menyebabkan seseorang melakukan kecurangan. Kesempatan adalah peluang yang memungkinkan kecurangan terjadi. Biasanya disebabkan karena pengendalian internal suatu organisasi yang lemah, kurangnya pengawasan, atau penyalahgunaan wewenang (Gagola dalam Diany, 2014). Pelaku kecurangan memerlukan suatu cara untuk membenarkan (merasionalisasi) atas tindakan yang mereka lakukan agar dapat diterima.

\section{Pengertian Efektivitas}

Dalam Kamus Besar Bahasa Indonesia (1992) dikemukakan efektiv berarti ada efeknya (akibatnya, pengaruhnya, kesannya) manjur atau mujarab, dapat membawa hasil. Berdasarkan pendapat di atas, efektivitas menjadi sangat penting karena mampu memberikan gambaran mengenai keberhasilan suatu organisasi dalam mencapai sasaran atau tujuan yang diharapkan.

Efektivitas pelaksanaan prosedur audit dalam pembuktian fraud (kecurangan) dapat diartikan sejauh mana hasil audit tersebut dapat menggambarkan info-info mengenai apa, siapa, kapan, dimana, kenapa, dan bagaimana tentang proses fraud yang terjadi.

\section{Pelaksanaan Prosedur Audit Investigasi}

Pusdiklatwas BPKP (2008:77) menjelaskan bahwa prosedur audit investigasi mencakup sejumlah tahapan yang secara umum dapat dikelompokkan menjadi lima tahap yaitu penelahaan informasi awal, perencanaan, pelaksanaan, pelaporan, dan tindak lanjut.

\section{Pengertian Kompetensi Auditor}

Kompetensi yang harus dimiliki oleh seorang auditor adalah memahami akan akuntansi dan auditing, serta telah mengikuti berbagai pelatihan auditor dan telah lulus Ujian Sertifikasi JFA yang dilakukan oleh BPKP. Berdasarkan Pasal 51 Peraturan Pemerintah Nomor 60 Taun 2008 Tentang Sistem Pengendalian Internal Pemerintah (SPIP) menyebutkan bahwa Syarat kompetensi keahlian sebagai auditor dipenuhi melalui keikutsertaan dan kelulusan program sertifikasi Jabatan Fungsional Auditor. Dalam penyusunan dan pelaksanaan prosedur audit, sudah semestinya seorang auditor memiliki kompetensi yang memadai. Lubis 
(2009) menyebutkan bahwa kompetensi teknis yang harus dimiliki oleh auditor adalah auditing, akuntansi, administrasi pemerintahan dan komunikasi. Selain itu, seorang auditor juga harus memiliki pengetahuan yang memadai di bidang hukum untuk membuktikan adanya suatu fraud. Berbekal pengetahuan tersebut, maka seorang auditor akan dapat menyusun dan melaksanakan prosedur audit dengan efektif.

\section{Pengertian Independensi Auditor}

Dalam Standar Profesional Akuntan Publik (SPAP) (IAI, 2001: 220.1) auditor diharuskan bersikap independen, artinya tidak mudah dipengaruhi, karena ia melaksanakan pekerjaannya untuk kepentingan umum. Mulyadi (2011) menyebutkan bahwa Independensi adalah keadaan bebas dari pengaruh, tidak dikendalikan oleh pihak lain, tidak tergantung pada orang lain. Alim dalam Ikra (2009) menyatakan bahwa kerjasama dengan obyek pemeriksaan yang terlalu lama dan berulang bisa menimbulkan kerawanan atas independensi yang dimiliki auditor. Belum lagi berbagai fasilitas yang disediakan obyek pemeriksaan selama penugasan dapat mempengaruhi obyektifitas auditor, serta bukan tidak mungkin auditor menjadi tidak jujur dalam mengungkapkan fakta yang menunjukkan rendahnya integritas auditor.

\section{Pengertian Profesionalisme}

Auditor adalah salah satu jenis profesi, sehingga membutuhkan profesionalisme pelakunya. Sedangkan, Profesionalisme adalah tingkah laku, kepakaran atau kualiti dari seseorang yang profesional (Longman, 1987). Sesuai pernyataan Iskandar (2013) Sebagai profesional, auditor mengakui tanggung jawabnya terhadap masyarakat, terhadap klien, dan terhadap rekan seprofesi, termasuk untuk berperilaku yang terhormat, sekalipun ini merupakan pengorbanan pribadi.

\section{Pengertian Kode Etik Auditor}

Menurut Peraturan Menteri Negara Pemberdayaan Aparatur Negara Nomor Per/05/M.Pan/03/2008 tentang Standar Audit Aparat Pengawasan Internal Pemerintah (APIP), kode etik tersebut meliputi:

1. Kode etik pejabat pengawas pemerintah/auditor dengan rekan sekerjanya.

2. Auditor dengan atasannya.

3. Auditor dengan objek pemeriksaaanya.

4. Auditor dengan masyarakat. 
Pengaruh Kompetensi, Independensi, Profesionalisme Dan Kepatuhan...

Kode etik profesi merupakan norma yang ditetapkan dan diterima oleh sekelompok profesi, yang mengarahkan atau memberi petunjuk kepada anggotanya bagaimana seharusnya berbuat dan sekaligus menjamin mutu profesi itu dimata masyarakat. Apabila anggota kelompok profesi itu menyimpang dari kode etiknya, maka kelompok profesi itu akan tercemar di mata masyarakat.

\section{Perumusan Hipotesis}

Kerangka Pemikiran

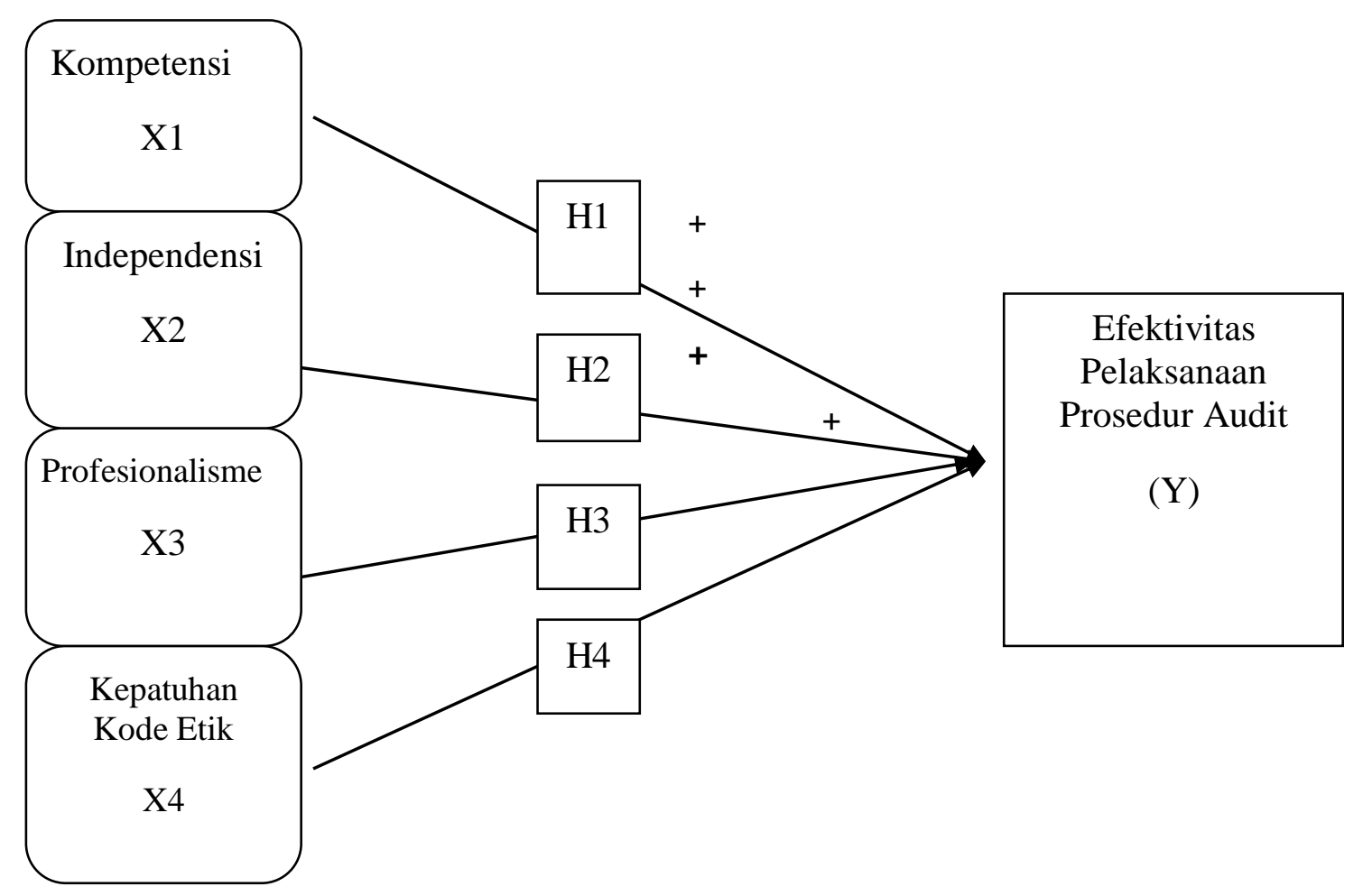

\section{METODOLOGI PENELITIAN}

\section{Rancangan Penelitian}

Metode yang digunakan dalam penelitian ini adalah metode penelitian kuantitatif. Data yang diperoleh selama penelitian diolah, dianalisis dan diproses lebih lanjut sehingga dapat menggambarkan mengenai hubungan antara variabel-variabel dari objek yang diteliti secara jelas. Pengujian hipotesis pada penelitian ini dilakukan melalui uji statistik analisis regresi linier berganda.

Dalam menguji hipotesis, quisioner digunakan untuk menjadi dasar dalam menarik kesimpulan penelitian. Pengumpulan data dalam diperoleh melalui survey dengan proses 
pengambilan sampel dari suatu populasi. Responden dalam penelitian ini yaitu para auditor investigatif di Perwakilan Badan Pengawasan Keuangan dan Pembangunan (BPKP) Jawa Tengah yang terletak di Semarang.

\section{Tempat dan Waktu}

Penelitian ini dilakukan di Perwakilan Badan Pengawasan Keuangan dan Pembangunan (BPKP) Jawa Tengah. Gedung kantor BPKP ini terletak di Jl. Raya Semarang Kendal Km.12 Semarang 50186. Penelitian dilakukan pada waktu yang telah ditentukan oleh perwakilan BPKP Provinsi Jawa Tengah.

\section{Populasi Penelitian}

Populasi penelitian ini adalah seluruh auditor di Perwakilan BPKP Provinsi Jawa Tengah sejumlah 320 orang auditor.

\section{Sampel Penelitian}

Sampel penelitian ini adalah auditor investigatif di Perwakilan BPKP Provinsi Jawa Tengah yang terdiri dari 42 sampel.

\section{Teknik Pengambilan Sampel}

Teknik random sampling yang digunakan memungkinkan peneliti memilih seluruh auditor investigatif di BPKP Provinsi Jawa Tengah sebagai sampel atau subjek penelitian.

\section{Teknik Pengumpulan Data}

peneliti memperoleh data berupa data primer, yaitu data yang langsung diperoleh dari penelitian lapangan melalui pengamatan langsung pada objek yang akan diteliti melalui teknik pengumpulan data berupa kuesioner dan observasi.

\section{Metode Penelitian}

Penelitian ini menggunakan lebih dari satu (empat) variabel independen yang berpengaruh terhadap variabel dependen. Maka model penelitian atau metode analisis data yang digunakan di penelitian ini adalah analisis regresi linier berganda.

\section{Teknis Analisis Data}

Uji Kualitas Data 
Pengaruh Kompetensi, Independensi, Profesionalisme Dan Kepatuhan...

Uji validitas digunakan untuk mengukur sah atau valid tidaknya suatu kuesioner. Suatu kuesioner dikatakan valid jika pertanyaan pada kuesioner mempu untuk mengungkapkan sesuatu yang akan diukur oleh kuesioner tersebut. Pengujian validitas ini menggunakan Pearson Correlation yaitu dengan cara menghitung korelasi antara skor masing-masing butir pertanyaan dengan total skor. Jika korelasi antara skor masing-masing butir pertanyaan dengan total skor mempunyai tingkat signifikansi di bawah 0,05 maka butir pertanyaan tersebut dinyatakan valid dan sebaliknya (Ghozali, 2005).

\section{Uji Reliabelitas Data}

Uji reliabilitas data adalah suatu uji yang dilakukan untuk mengukur suatu kuesioner yang merupakan indikator dari suatu variabel atau konstruk. Suatu kuesioner dikatakan reliable atau handal jika jawaban seseorang dalam kuesioner konsisten atau stabil dari waktu ke waktu. Suatu kuesioner dikatakan relaibel atau handal jika memberikan nilai cronbach alpha di atas 0,6 (Ghozali, 2005).

\section{Uji Asumsi Klasik}

\section{Uji Normalitas}

Uji normalitas bertujuan untuk menguji apakah dalam model regresi variabel terikat dan variabel bebas keduanya apakah mempunyai distribusi normal atau tidak. Model regresi yang baik harus mempunyai distribusi normal atau mendekati normal (Ghozali, 2005).

\section{Uji Multikolinieritas}

Uji Multikolonieritas bertujuan untuk menguji apakah model regresi ditemukan adanya korelasi atar variabel bebas (Independen). Model korelasi yang baik seharusnya tidak terjadi korelasi di antara variabel independen.

\section{Uji Heterokedastisitas}

Uji heteroskedastisitas dilakukan untuk mengetahui apakah dalam sebuah model regresi terjadi ketidaksamaan varians dari residual suatu pengamatan ke pengamatan lain. Jika varians dari residual suatu pengamatan ke pengamatan lain tetap disebut homokedastisitas, sedangkan untuk varians yang berbeda disebut heterokedastisitas. Menurut Umar (2000) model regresi yang baik adalah model yang heterokedastisitas.

\section{Pengujian Hipotesis}

Uji F 
Secara simultan, pengujian hipotesis dilakukan dengan uji F-test. Menurut Ghozali (2005): "uji statistik F pada dasarnya menunjukkan apakah semua varibel independen atau bebas yang dimasukkan dalam model mempunyai pengaruh secara bersama- sama terhadap variabel dependen/terikat".

Uji t

Menurut Ghozali (2005) uji statistik t pada dasarnya menunjukkan seberapa jauh pengaruh satu variabel independen secara individual dalam menerangkan variabel dependen.

\section{Pembahasan}

\section{Statistik Deskriptif}

Dalam penelitian ini terdapat lima variabel penelitian (KOMP, INDEP, PROFES, KD_ETIK, dan EFEKTIV) dengan jumlah sampel secara keseluruhan sebanyak 42 sampel yang diterima. Dengan nilai minimum sebagai nilai terendah untuk setiap variabel, dan nilai maksimum untuk nilai tertinggi untuk setiap variabel dalam penelitian. Dalam tabel juga dapat dilihat mean dari setiap nilai dari masing-masing variabel. Selain itu juga dapat dilihat standar deviasi nilai dari data masing-masing variabel.

\section{Statistik Deskriptif}

\begin{tabular}{|c|c|c|c|c|c|c|}
\hline & $\mathrm{N}$ & Minimum & Maximum & $\mathrm{Me}$ & & $\begin{array}{c}\text { Std. } \\
\text { Deviation }\end{array}$ \\
\hline & & & & \multicolumn{3}{|c|}{ Std. } \\
\hline & Statistic & Statistic & Statistic & Statistic & Error & Statistic \\
\hline KOMP & 42 & 18.00 & 25.00 & 23.4762 & .29364 & 1.90299 \\
\hline INDEP & 42 & 17.00 & 25.00 & 23.7381 & .32342 & 2.09598 \\
\hline PROFES & 42 & 19.00 & 25.00 & 23.4524 & .27094 & 1.75586 \\
\hline KD_ETIK & 42 & 20.00 & 25.00 & 23.6190 & .28707 & 1.86040 \\
\hline EFEKTIV & 42 & 66.00 & 100.00 & 89.7857 & 1.30688 & 8.46956 \\
\hline $\begin{array}{l}\text { Valid N } \\
\text { (listwise) }\end{array}$ & 42 & & & & & \\
\hline
\end{tabular}

Sumber: Hasil Pengolahan Data

\section{Uji Kualitas Data}

\section{Uji Validitas}


Pengaruh Kompetensi, Independensi, Profesionalisme Dan Kepatuhan...

Uji validitas digunakan untuk menunjukkan sejauh mana alat ukur tersebut mampu mengukur apa yang diukur. Uji valilitas dalam penelitian ini dilakukan terhadap 40 pertanyaan yang terdiri dari 5 pertanyaan untuk variabel X1 (kompetensi), 5 pertanyaan untuk variabel X2 (independensi), 5 pertanyaan untuk variabel X3 (profesionalisme), 5 pertanyaan untuk variabel X4 (kode etik), dan 20 pertanyaan untuk variabel Y (Efektivitas Pelaksanaan Prosedur Audit). Uji validitas menggunakan program SPSS 16.0.

Uji ini dilakukan dengan cara membandingkan angka $r$ hitung dan $r$ table. Jika $r$ hitung lebih besar daripada $r$ tabel maka item dikatakan valid dan sebaliknya jika $r$ hitung lebih kecil dari $r$ tabel maka item dikatakan tidak valid. Sedangkan, $r$ tabel dari penelitian ini adalah N-2 $=42-2=40$ dengan tingkat uji signifikansi dua arah sebesar 0,01 yaitu 0,3932. Berdasarkan pengujian validitas instrumen seluruh pertanyaan variabel X (Kompetensi, Independensi, Profesionalisme, dan Kepatuhan pada Kode Etik) memiliki $r$ hitung yang lebih besar dari $r$ tabel sehingga semua pertanyaan dapat dinyatakan valid. Secara rinci dapat dilihat pada tabel berikut:

Uji Validitas Variabel X

\begin{tabular}{ccccc}
\hline Variabel & Pertanyaan & r tabel & r hitung & Keterangan \\
\hline Kompetensi & X1.1 & 0.3932 & 0.790 & Valid \\
& X1.2 & 0.3932 & 0.692 & Valid \\
X1.3 & 0.3932 & 0.850 & Valid \\
Independensi & X1.4 & 0.3932 & 0.919 & Valid \\
& X1.5 & 0.3932 & 0.762 & Valid \\
& X2.2 & 0.3932 & 0.874 & Valid \\
Independensi & X2.3 & 0.3932 & 0.893 & Valid \\
& X2.4 & 0.3932 & 0.817 & Valid \\
& X2.5 & 0.3932 & 0.839 & Valid \\
X3.2 & 0.3932 & 0.874 & Valid \\
Kepatuhan & X3.3 & 0.3932 & 0.893 & Valid \\
& X3.4 & 0.3932 & 0.817 & Valid \\
& X3.5 & 0.3932 & 0.893 & Valid \\
& X4.2 & 0.3932 & 0.790 & Valid \\
& X4.3 & 0.3932 & 0.734 & Valid \\
& X4.4 & 0.3932 & 0.576 & Valid \\
& X4.5 & 0.3932 & 0.652 & Valid \\
\hline Sumber: Hasil Pengolid & & & Valid \\
\hline
\end{tabular}

Sumber : Hasil Pengolahan SPSS 
Berdasarkan pengujian validitas instrumen seluruh pertanyaan variabel Y (Efektivitas Pelaksanaan Prosedur Audit) memiliki $r$ hitung yang lebih besar dari $r$ tabel sehingga semua pertanyaan dapat dinyatakan valid. Secara rinci dapat dilihat pada tabel berikut:

\section{Uji Validitas Variabel Y (Efektivitas Pelaksanaan Prosedur Audit)}

\begin{tabular}{ccccc}
\hline Variabel & Pertanyaan & r tabel & r hitung & Keterangan \\
\hline Efektifitas & Y.1 & 0.3932 & 0.710 & Valid \\
Pelaksanaan & Y.2 & 0.3932 & 0.715 & Valid \\
Prosedur Audit & Y.3 & 0.3932 & 0.652 & Valid \\
& Y.4 & 0.3932 & 0.714 & Valid \\
& Y.5 & 0.3932 & 0.692 & Valid \\
& Y.6 & 0.3932 & 0.508 & Valid \\
& Y.7 & 0.3932 & 0.532 & Valid \\
& Y.8 & 0.3932 & 0.530 & Valid \\
& Y.9 & 0.3932 & 0.543 & Valid \\
& Y.10 & 0.3932 & 0.572 & Valid \\
& Y.11 & 0.3932 & 0.636 & Valid \\
& Y.12 & 0.3932 & 0.677 & Valid \\
& Y.13 & 0.3932 & 0.587 & Valid \\
& Y.14 & 0.3932 & 0.712 & Valid \\
& Y.15 & 0.3932 & 0.480 & Valid \\
Y.16 & 0.3932 & 0.703 & Valid \\
& Y.17 & 0.3932 & 0.623 & Valid \\
Y.18 & 0.3932 & 0.616 & Valid \\
Y.19 & 0.3932 & 0.725 & Valid \\
Y.20 & 0.3932 & 0.665 & Valid \\
\hline
\end{tabular}

Sumber : Hasil Pengolahan SPSS

\section{Uji Reabilitas}

Uji reabilitas digunakan untuk mengetahui konsistensi alat ukur, apakah alat pengukur yang digunakan dapat diandalkan dan tetap konsisten jika pengukuran tersebut diulang. Suatu kuesioner dikatakan relaibel atau handal jika memberikan nilai cronbach alpha di atas 0,6 (Ghozali, 2005). Dapat dilihat pada tabel berikut:

\section{Uji Reliabilitas}

\begin{tabular}{ccc}
\hline $\begin{array}{c}\text { Cronbach's } \\
\text { Alpha }\end{array}$ & Batas Reliabilitas & Keterangan \\
\hline 0.943 & 0,6 & Reliabel \\
\hline
\end{tabular}

Sumber : Hasil Pengolahan SPSS 
Pengaruh Kompetensi, Independensi, Profesionalisme Dan Kepatuhan...

\section{Uji Asumsi Klasik}

\section{Uji Normalitas}

Uji normalitas ini dilakukan dengan analisis Grafik Normal P-P Plot dimana normalitas dapat dideteksi dengan melihat penyebaran data (titik) pada sumbu diagonal dari grafik normal. Hasil pengujian normalitas dengan menggunakan SPSS dapat dinyatakan pada gambar berikut :

\section{Normal P-P Plot of Regression Standardized Residual}

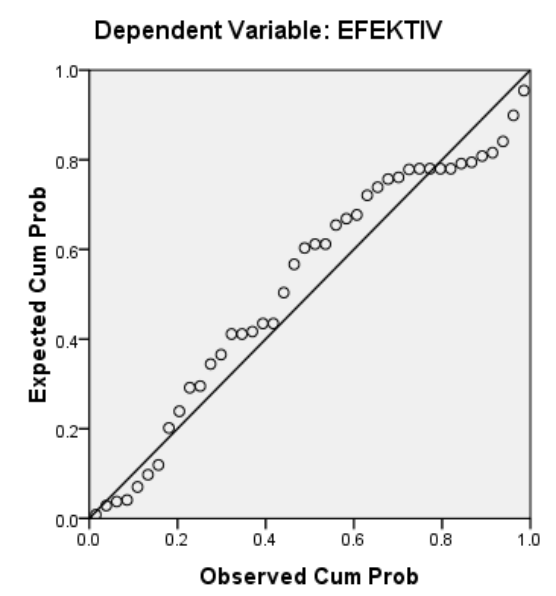

Sumber: Hasil Pengolahan Data

Gambar di atas memperlihatkan penyebaran data di sekitar garis diagonal dan mengikuti arah garis diagonal, maka model regresi memenuhi unsur normalitas (data menyebar di sekitar garis diagonal dan mengikuti arah garis diagonalnya) atau dengan kata lain model regresi layak dipakai untuk prediksi Efektivitas Pelaksanaan Prosedur Audit berdasarkan masukan dari variabel independennya.

\section{Uji Multikolinieritas}

Multikolinearitas menunjukkan bahwa antara variabel independen mempunyai hubungan langsung (korelasi) yang sangat kuat. Multikolinearitas terjadi jika nilai Variance Inflation Factor (VIF) lebih besar dari 10 atau nilai Tolerance lebih kecil 0,10 (Hair et. al. 1998). Dari hasil pengolahan data statistik diperoleh tabel pengujian multikolinearitas sebagai berikut: 
Tabel 4.5

Hasil Uji Multikolinearitas

\begin{tabular}{llll}
\hline & & \multicolumn{2}{c}{ Collinearity } \\
Statistics \\
\cline { 3 - 4 } Model & & Tolerance & VIF \\
\hline 1 & (Constant) & & \\
& KOMP & .581 & 1.720 \\
& INDEP & .320 & 3.123 \\
& PROFES & .270 & 3.708 \\
& KD_ETIK & .385 & 2.597 \\
\hline
\end{tabular}

Sumber: Hasil Pengolahan Data

Berdasarkan tabel di atas, diketahui seluruh variabel independen yaitu KOMP, INDEP, PROFES, dan KD_ETIK mempunyai nilai VIF kurang dari batas maksimal 10 atau nilai Tolerance lebih dari 0,1. Sehingga H0 diterima, yang artinya variabel independen tersebut tidak menunjukkan adanya gejala multicolinearitas (tidak ada hubungan yang sangat kuat antara variabel independen dengan variabel independen lainnya). Dengan demikian tidak terjadi pelanggaran asumsi multikolinearitas pada model persamaan regresi.

\section{Uji Heterokedastisitas}

Uji Heteroskedastisitas dilakukan dengan membuat Scatterplot (alur sebaran) antara residual dan nilai prediksi variabel terikat yang telah distandarisasi. Hasil uji heterokedastisitas dapat dilihat pada gambar berikut ini :

\section{Scatterplot}

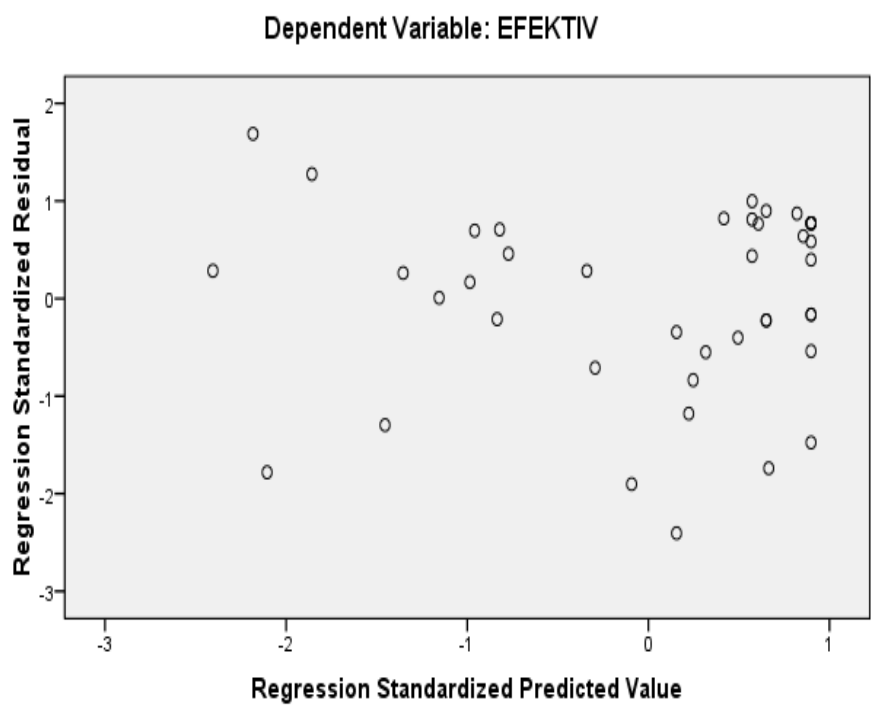


Pengaruh Kompetensi, Independensi, Profesionalisme Dan Kepatuhan...

Dari gambar diatas terlihat bahwa sebaran titik tidak membentuk suatu pola/alur tertentu, sehingga dapat disimpulkan tidak terjadi heterokedastisitas atau dengan kata lain terjadi homoskedastisitas.

\section{Analisis Regresi}

Uji F

Uji F digunakan untuk mengetahui apakah variabel independen yang meliputi Kompetensi, Independensi, Profesionalisme dan Kepatuhan Kode Etik Auditor Investigatif terhadap variabel dependennya yaitu Efektivitas Pelaksanaan Prosedur Audit dalam Pembuktian Fraud (Kecurangan).

\begin{tabular}{|c|c|c|c|c|c|c|}
\hline \multicolumn{7}{|c|}{ Hasil Uji F } \\
\hline Model & & $\begin{array}{l}\text { Sum of } \\
\text { Squares }\end{array}$ & Df & $\begin{array}{c}\text { Mean } \\
\text { Square }\end{array}$ & $\mathrm{F}$ & Sig. \\
\hline \multirow[t]{3}{*}{1} & Regression & 1885.226 & 4 & 471.307 & 16.516 & $.000^{\mathrm{a}}$ \\
\hline & Residual & 1055.845 & 37 & 28.536 & & \\
\hline & Total & 2941.071 & 41 & & & \\
\hline
\end{tabular}

Sumber: Hasil Pengolahan Data

Berdasarkan tabel di atas, yang merupakan hasil uji $\mathrm{F}$ (uji simultan), variabel-variabel independensi meliputi Kompetensi, Independensi, Profesionalisme dan Kepatuhan Kode Etik Auditor Investigatif secara bersama-sama berpengaruh signifikan terhadap variabel dependennya yaitu Efektivitas Pelaksanaan Prosedur Audit dalam Pembuktian Fraud (Kecurangan), yang ditunjukkan dengan Fhitung 16,516 dengan taraf signifikansi 0,000 $(<0,10)$ sehingga dapat disimpulkan H0 diterima yang artinya variabel independent secara bersama -sama berpengaruh pada variabel dependennya.

\section{Uji goodness of fit-model $\left(R^{2}\right)$}

Pengukuran ini dimaksudkan untuk menilai kebaikan model (goodness of fit) dari persamaan regresi, yaitu memberikan proporsi atau persentase variasi total dalam variabel terikat yang dijelaskan oleh variabel bebas. Nilai $\mathrm{R}^{2}$ terletak antara $0-1$, dan kecocokan model dikatakan lebih baik kalau $\mathrm{R}^{2}$ semakin mendekati 1 . Penelitian ini menggunakan variabel independent lebih dari 2, untuk itu digunakan adjusted R Square. Suatu sifat penting $\mathrm{R}^{2}$ adalah nilainya merupakan fungsi yang tidak pernah menurun dari banyaknya variabel bebas yang ada dalam model. Istilah penyesuaian berarti nilai $\mathrm{R}^{2}$ sudah disesuaikan dengan 
banyaknya variabel (derajat bebas) dalam model. Memang, $\mathrm{R}^{2}$ yang disesuaikan ini juga akan meningkat bersamaan meningkatnya jumlah variabel, tetapi peningkatannya relatif kecil.

\section{Hasil Analisis Kebaikan Model}

\begin{tabular}{|c|c|c|c|c|c|}
\hline Model & $\mathrm{R}$ & R Square & $\begin{array}{l}\text { Adjusted } \\
\text { R Square }\end{array}$ & $\begin{array}{l}\text { Std. Error } \\
\text { of the } \\
\text { Estimate }\end{array}$ & $\begin{array}{l}\text { Durbin- } \\
\text { Watson }\end{array}$ \\
\hline 1 & $.801^{\mathrm{a}}$ & .641 & .602 & 5.34194 & 1.777 \\
\hline
\end{tabular}

Dari hasil pengujian goodness of fit-model, didapat adjusted $\mathrm{R}^{2}$ sebesar 0,602 atau 60,2 $\%$ artinya 60,2 \% variasi dari variabel dependent yaitu Kompetensi, Independensi, Profesionalisme dan Kepatuhan Kode Etik Auditor Investigatif yang dimasukkan ke dalam model, sedangkan sisanya sebesar 39,8 \% dipengaruhi oleh variabel lain yang tidak dimasukkan ke dalam model. Rsquare yang tinggi dari hasil penelitian dapat disebabkan oleh data penelitian yang sedikit dan variabel independen yang banyak. Maka dari itu, hasil ini riskan untuk dijadikan bahan pertimbangan dalam mengambil keputusan, karena selain itu masih banyak variabel lain yang berhubungan dengan Efektivitas Pelaksanaan Prosedur Audit dalam Pembuktian Fraud (Kecurangan).

\section{Uji Secara Parsial (Uji t)}

Untuk mengetahui besarnya pengaruh antara variabel independen yaitu independensi Kompetensi, Independensi, Profesionalisme dan Kepatuhan Kode Etik Auditor Investigatif terhadap variabel dependent yaitu Efektivitas Pelaksanaan Prosedur Audit dalam Pembuktian Fraud (Kecurangan), maka digunakan nilai hasil estimasi uji t dengan membandingkan nilai probabilitasnya. Apabila nilai probabilitas kurang dari $\alpha=10 \%$, maka dapat dikatakan mempunyai pengaruh. Hasil dari pengujian hipotesis yang menggunakan program SPSS versi 16, diperoleh hasil uji hipotesis yang merupakan uji hubungan kausalitas dari masing;masing variabel penelitian sebagaimana disajikan pada tabel berikut ini:

\section{Hasil Uji T}

\begin{tabular}{|c|c|c|c|c|c|c|}
\hline \multirow{2}{*}{\multicolumn{2}{|c|}{ Model }} & \multicolumn{2}{|c|}{$\begin{array}{l}\text { Unstandardized } \\
\text { Coefficients }\end{array}$} & \multirow{2}{*}{$\begin{array}{c}\text { Standardized } \\
\text { Coefficients } \\
\text { Beta }\end{array}$} & \multirow[b]{2}{*}{$\mathrm{T}$} & \multirow[b]{2}{*}{ Sig. } \\
\hline & & B & Std. Error & & & \\
\hline \multirow[t]{4}{*}{1} & (Constant) & -8.603 & 12.704 & & -.677 & .502 \\
\hline & KOMP & .529 & .575 & .119 & .920 & .364 \\
\hline & INDEP & .292 & .703 & .072 & .416 & .680 \\
\hline & PROFES & 1.679 & .915 & .348 & 1.836 & .074 \\
\hline
\end{tabular}


Pengaruh Kompetensi, Independensi, Profesionalisme Dan Kepatuhan...

\begin{tabular}{llllll} 
KD_ETIK & 1.679 & .723 & .369 & 2.323 & .026 \\
\hline
\end{tabular}

Sumber : Hasil pengolahan data

1. Pengaruh Kompetensi Auditor terhadap Efektivitas Pelaksanaan Prosedur Audit dalam Pembuktian Fraud (Kecurangan)

Berdasarkan tabel 4.12, hasil pengolahan data didapatkan thitung sebesar 0,920 dan tingkat signifikan sebesar 0,364, Kompetensi Auditor tidak berpengaruh signifikan terhadap Efektivitas Pelaksanaan Prosedur Audit dalam Pembuktian Fraud (Kecurangan) karena mempunyai signifikansi lebih dari $10 \%(\alpha>0,1)$. Berdasarkan nilai B sebesar 0,529 dapat disimpulkan bahwa Kompetensi Auditor berpengaruh positif terhadap Efektivitas Pelaksanaan Prosedur Audit dalam Pembuktian Fraud (Kecurangan).

2. Pengaruh Independensi Auditor terhadap Efektivitas Pelaksanaan Prosedur Audit dalam Pembuktian Fraud (Kecurangan)

Berdasarkan tabel 4.12, hasil pengolahan data didapatkan thitung sebesar 0,416 dan tingkat signifikan sebesar 0,680, Independensi Auditor tidak berpengaruh signifikan terhadap Efektivitas Pelaksanaan Prosedur Audit dalam Pembuktian Fraud (Kecurangan) karena mempunyai signifikansi lebih dari $10 \%(\alpha>0,1)$. Berdasarkan nilai B sebesar 0,292 dapat disimpulkan bahwa Independensi Auditor berpengaruh positif terhadap Efektivitas Pelaksanaan Prosedur Audit dalam Pembuktian Fraud (Kecurangan).

3. Pengaruh Profesionalisme Auditor terhadap Efektivitas Pelaksanaan Prosedur Audit dalam Pembuktian Fraud (Kecurangan)

Berdasarkan tabel 4.12, hasil pengolahan data didapatkan thitung sebesar 1,836 dan tingkat signifikan sebesar 0,074, Profesionalisme Auditor berpengaruh signifikan terhadap Efektivitas Pelaksanaan Prosedur Audit dalam Pembuktian Fraud (Kecurangan) karena mempunyai signifikansi kurang dari $10 \%(\alpha<0,1)$. Berdasarkan nilai B sebesar 1,679 dapat disimpulkan bahwa Profesionalisme Auditor berpengaruh positif terhadap Efektivitas Pelaksanaan Prosedur Audit dalam Pembuktian Fraud (Kecurangan).

4. Pengaruh Kode Etik Auditor terhadap Efektivitas Pelaksanaan Prosedur Audit dalam Pembuktian Fraud (Kecurangan)

Berdasarkan tabel 4.12, hasil pengolahan data didapatkan thitung sebesar 1,836 dan tingkat signifikan sebesar 0,026, Kode Etik Auditor berpengaruh signifikan terhadap Efektivitas Pelaksanaan Prosedur Audit dalam Pembuktian Fraud (Kecurangan) karena mempunyai signifikansi kurang dari $10 \% \quad(\alpha<0,1)$. Berdasarkan nilai B sebesar 1,679 dapat 
disimpulkan bahwa Kode Etik Auditor berpengaruh positif terhadap Efektivitas Pelaksanaan Prosedur Audit dalam Pembuktian Fraud (Kecurangan).

\section{Persamaan Regresi Linier Berganda}

Dari pengolahan data SPSS 16.0 dapat disimpulkan hubungan Kompetensi, Independensi, Profesionalisme dan Kepatuhan Kode Etik Auditor Investigatif terhadap Efektivitas Pelaksanaan Prosedur Audit dalam Pembuktian Fraud (Kecurangan) dengan rumus regresi linier berganda sebagai berikut:

EFEKTIV =-8,603+0,529KOMP+0,292INDEP+1,679 PROFES +1,679KD_ETIK

\section{Pembahasan}

Berdasarkan hasil pengujian dalam penelitian ini, kompetensi, independensi, profesionalisme dan kepatuhan pada kode etik secara bersama-sama berpengaruh sebesar 60,2 \% terhadap efektivitas pelaksanaan prosedur audit, sedangkan sisanya sebesar $39.8 \%$ dipengaruhi oleh variabel lain di luar penelitian. Sedangkan, secara parsial masing-masing variabel menunjukan pengaruh positif akan tetapi yang signifikan hanya variabel kepatuhan pada kode etik. Hal ini terlihat dari koefisian regresi kepatuhan pada kode etik sebesar 0.026.

\section{Pengaruh Kompetensi Terhadap Efektivitas Pelaksanaan Prosedur Audit}

Hasil pengujian dalam penelitian ini menunjukan bahwa kompetensi berpengaruh positif terhadap efektivitas pelaksanaan prosedur audit, dengan kata lain H1 diterima. Hal ini menunjukan bahwa semakin baik kompetensi yang dimiliki seorang auditor investigatif maka semakin efektif pula pelaksanaan prosedur audit yang dilakukannya. Hasil penelitian ini sejalan dengan hasil penelitian yang dilakukan oleh Fitriyani (2012), Zuliha (2008), dan Patunru (2014).

\section{Pengaruh Independensi terhadap efektivitas pelaksanaan prosedur Audit}

Hasil Hasil pengujian dalam penelitian ini menunjukan bahwa independensi berpengaruh positif terhadap efektivitas pelaksanaan prosedur audit, dengan kata lain H2 diterima. Hal ini menunjukan bahwa semakin besar sikap independensi yang dimiliki seorang auditor investigatif maka pelaksanaan prosedur audit yang dilaksanakan akan semakin efektiv. Sebaliknya, jika seorang auditor tidak bersikap independen atau keindependensiannya terganggu maka pelaksanaan prosedur audit yang dilaksanakan menjadi tidak efektif bahkan ada beberapa prosedur yang tidak dilaksnakan.

Pengaruh Profesionalisme Terhadap Efektivitas Pelaksanaan Prosedur Audit 
Pengaruh Kompetensi, Independensi, Profesionalisme Dan Kepatuhan...

Hasil pengujian dalam penelitian ini menunjukan bahwa profesionalisme berpengaruh positif terhadap efektivitas pelaksanaan prosedur audit, dengan kata lain H3 diterima. Hal ini menunjukan bahwa semakin besar tingkat profesionalisme yang dimiliki seorang auditor investigatif maka pelaksanaan prosedur audit yang dilaksanakan akan semakin efektiv. Sebaliknya, jika seorang auditor bersikap tidak profesional maka pelaksanaan prosedur audit yang dilaksanakan menjadi tidak efektif.

\section{Pengaruh Kepatuhan pada Kode Etik Terhadap Efektivitas Pelaksanaan Prosedur Audit}

Hasil pengujian dalam penelitian ini menunjukan bahwa kepatuhan pada kode etik berpengaruh positif terhadap efektivitas pelaksanaan prosedur audit, dengan kata lain H4 diterima. Hal ini menunjukan bahwa semakin patuh seorang auditor terhadap kode etik maka semakin efektif pula pelaksanaan prosedur audit yang dilakukannya. Pengaruh signifikan menunjukan bahwa kepatuhan pada kode etik memiliki peranan yang sangat penting dalam efektivitas pelaksanaan prosedur audit.

\section{Kesimpulan dan Saran}

\section{Kesimpulan}

Berdasarkan hasil pembahasan hasil penelitian, maka ditarik kesimpulan sebagai berikut:

1. Secara simultan kompetensi, independensi, profesionalisme dan kepatuhan pada kode etik secara bersama-sama berpengaruh positif sebesar 60,2 \% terhadap efektivitas pelaksanaan prosedur audit;

2. Secara parsial kompetensi, independensi, profesionalisme dan kepatuhan pada kode etik masing-masing berpengaruh positif, tetapi kepatuhan pada kode etik memiliki tingkat signifikasni paling besar.

\section{Keterbatasan Penelitian}

1. Tingkat generalisasi dari penelitian ini masih kurang karena penelitian ini hanya melibatkan satu institusi saja yaitu Perwakilan BPKP Provinsi Jawa Tengah, sehingga kesimpulan yang diambil memiliki potensi hanya berlaku pada Perwakilan BPKP Provinsi Jawa Tengah saja tidak dapat digeneralisasikan ke seluruh perwakilan BPKP;

2. Penelitian ini hanya menggunakan kuisioner sehingga masih ada kemungkinan kelemahan-kelemahan yang ditemui antara lain jawaban yang tidak cermat dan serius, 
jawaban yang asal-asalan atau tidak jujur dan pertanyaan-pertanyaan yang kurang bisa dipahami oleh responden;

3. Variabel yang digunakan hanya sebatas empat variabel yaitu kompetensi, independensi, profesionalisme dan kepatuhan pada kode etik sehingga masih banyak variabel yang mempengaruhi efektifitas pelaksanaan prosedur audit di luar empat variabel tersebut.

\section{Saran}

Berikut saran peneliti untuk menperbaiki kekurangan dan keterbatasan-keterbatasan yang telah diungkapkan sebelumnya :

1. Memperbanyak populasi penelitian yang mencakup seluruh unit kerja BPKP sehingga kesimpulan yang diambil dapat digeneralisasikan ke seluruh unit kerja BPKP.

2. Menggunakan data-data sekunder misalkan penilaian kinerja pegawai, hasil evaluasi dari Inspektorat BPKP terkait efektifitas pelaksaan prosedur audit dan lain sebagainya.

3. Menambah variabel-variabel lain, misalkan motivasi kerja, pola mutasi, dan pengalaman kerja. 
Pengaruh Kompetensi, Independensi, Profesionalisme Dan Kepatuhan...

\section{DAFTAR PUSTAKA}

Astuti, Puji. Jurnal. 2012, Politik Korupsi : Kendala Sistemik Pemberantasan Korupsi di Indonesia.

Badjuri, Achmat. 2011. Faktor-Faktor yang Berpengaruh Terhadap Kualitas Audit Auditor Independen pada Kantor Akuntan Publik (Kap) di Jawa Tengah. Semarang. Universitas Stikubank.

Biana, Adha. Akram dan Ika, Sukriah. 2009. Jurnal. Pengaruh Pengalaman Kerja, Independensi, Obyektifitas, Integritas, dan Kompetensi terhadap Kualitas Hasil Pemeriksaan. Simposium Nasional Akuntansi XII, Palembang

BPKP, 2009. Panduan Penugasan Bidang Investigasi tahun 2009. Jakarta

Diany, Yuvita Avrie. 2014. Determinan Kecurangan Laporan Keuangan: Pengujian Teori Fraud Triangle. Semarang. Universitas Diponegoro.

Djelantik, Sukawarsini. Jurnal. 2008, Korupsi, Kemiskinan, dan Masalah Negara Berkembang. Jakarta. Jurnal Administrasi Publik, Vol. 5, No. 1.

Ghozali, Imam. 2005. Aplikasi Analisis Multivariate dengan Program SPSS Edisi3. Semarang: Badan Penerbit Universitas Diponegoro.

http://jateng.tribunnews.com/2016/03/29/ma-menangkan-gugatan-mantan-kepala-bpnkabupaten-semarang-terhadap-bpkp-jawa-tengah

Instruksi Presiden RI Nomor 5 Tahun 2004 tentang Percepatan Pemberantasan Korupsi

Intruksi Presiden RI Nomor 9 Tahun 2014 tentang Peningkatan Kualitas Sistem Pengendalian Intern dan Keandalan Penyelenggaraan Fungsi Pengawasan Intern Dalam Rangka Mewujudkan Kesejahteraan Rakyat.

Iskandar, Kaka 2013. Pengaruh Profesionalisme Auditor Terhadap Tingkat Materialitas Dan Risiko Audit. Diakses dari http://iskandaaar.blogspot.co.id/2013/11/pengaruhprofesionalisme-auditor.html

Karyono, 2002, Fraud Auditing. Jakarta .Journal The WInnERS, Vol. 3 No. 2.

Longman, 1995, Dictionary Of Contemporary English. Harlow.Pearson PLC

Lubis, Haslinda. 2009. Pengaruh keahlian, Independensi, Kecermatan Profesional dan Kepatuhan pada Kode Etik terhadap Kualitas Auditor. Medan.. Universitas Sumatera Utara.

Mulyadi. 2011. Auditing. Jakarta : Salemba Empat.

Patunru, A. Arini Lestari. 2014. Pengaruh Kemampuan Auditor Investigatif Terhadap Efektivitas Pelaksanaan Prosedur Audit Dalam Pembuktian Kecurangan. Makassar.Universitas Hasanuddin.

Peraturan Menteri Negara Pemberdayaan Aparatur Negara Nomor Per/05/M.Pan/03/2008 tentang Standar Audit Aparat Pengawasan Internal Pemerintah (APIP) 
Peraturan Pemerintah Nomor 60 Taun 2008 Tentang Sistem Pengendalian Internal Pemerintah (SPIP)

Pusdiklatwas BPKP. 2008. Fraud Auditing. Makalah disajikan dalam Diklat Penjenjangan Auditor Tim, Bogor, Desember

Sekaran, Uma dan R. Bougie. 2014. Research Methods for Business-A Skill Building Approach6th Edition. United Kingdom: John Wiley\&amp;Sons Ltd.

Sugiyono. 2008. Metode Penelitian Bisnis. Bandung: CV. Alfabeta.

Sukriah, Ikra. 2009. Pengaruh Pengalaman Kerja, Independensi, Obyektifitas, Integritas dan Kompetensi Terhadap Kualitas Hasil Pemeriksaan. Jakarta. Universitas Indonesia.

Suradi. 2005. Mengapa Seseorang Korupsi? Palembang. Balai Diklat Keuangan

Tuanakotta, Theodorus M. 2012. Akuntansi Forensik dan Audit Investigatif. Jakarta: Salemba Empat

Undang-undang nomor 20 Tahun 2001 tentang Pemberantasan Tindak Pidana Korupsi

Widyasari, Malikha. 2010. Analisis Faktor -Faktor Yang Mempengaruhi Kualitas Hasil Kerja Auditor Internal Dan Eksternal. Semarang. Universitas Diponegoro. 